\title{
Safe use of induced hypotension in a patient with cirrhotic liver disease
}

Induced hypotension was used in a patient with chronic active hepatitis and cirrosis presenting for clipping of an intracranial aneurysm. A mean arterial pressure of $50 \mathrm{mmHg}$ was produced with a combination of sodium nitroprusside and labetalol. The patient sustained no postoperative changes in hepatic functirn. Previous stredies have examined the effects of indured hypotension on the function of the normal tiver, but there is relatively little information available on its effects in the presence of liver disease. The lack of an adverse auicome in this patient does not prove the safery of this technique in patients with liver disease; further studies of this patient group are required.

Induced hypotension, often to profound levels, is indicated for clipping of intracranial aneurysms, both to facilitate surgery and to prevent intraoperative aneurysm rupture. Information is available conceming brain, kidney, and cardiac function during induced hypotension.' Hepatic disease is commonly listed as a relative contraindication to its use. Since the liver has little or no ability to autoregulate, ${ }^{2}$ blood flow may decline passively with systemic blood pressure, and in an already diseased liver, one would be concerned about the possible risk of hepatic ischaemia. We report the successful use of sodium nitroprusside-induced hypotension in a patient with chronic active hepatitis and cirrhosis for intracranial aneurysm surgery.

\section{Case report}

A 36 -year-old, $80 \mathrm{~kg}$ woman was scheduled to undergo craniotomy for clipping of a right internal carotid artery

\section{Key words}

SURGERY: cerebral aneurysm; HYPOTENSION: induced; LIVER: cirrhosis; HEPATITIS: chronic active.

From the Division of Anesthesiology, The Cleveland Clinic Foundation, Cleveland, Ohio

Address correspondence to: Dr. Roth, Department of Anesthesia and Critical Care, University of Chicago Medical Center, Box 428, 5841 South Maryland Avenue, Chicago, Illinois, 60637. aneurysm. Her past history included hepatitis B infection at age 12, with subsequent biopsy-proven chronic active hepatitis and cirrhosis. Several bouts of upper gastrointestinal bleeding and hepatic encephalopathy had occurred within five years of the current admission. Angiograms showed portal hypertension and oesophageal varices. The patient's medications included cimetidine $300 \mathrm{mg}$ q.i.d., spironolactone $100 \mathrm{mg}$ b.i.d., and lactulose $20 \mathrm{ml}$ b.i.d. Preoperative physical examination revealed jaundice, finger clubbing, palmar erythema, and spider angiomata. A grade III/VI systolic ejection murmur was audible at the left sternal border and mild ascites was present

The haemoglobin was $11.9 \mathrm{~g} \cdot \mathrm{dl}^{-1}$, platelet count $120,000 \mathrm{~mm}^{-3}$, prothrombin time (PT) $15.8 \mathrm{sec}$ (control 10-13) and partial thromboplastin time (PTT) $35.4 \mathrm{sec}$ (control 21-31). The abnormal PT and PTT failed to reverse with vitamin $\mathrm{K}$ administration. The serum albumin was $2.6 \mathrm{~g} \cdot \mathrm{dl}^{-1}$, total protein $6.2 \mathrm{~g} \cdot \mathrm{dl}^{-1}$, and total bilirubin $5.6 \mathrm{mg} \cdot \mathrm{dl}^{-1}$. Lactate dehydrogenase (LDH) was $310 \mathrm{IU} \cdot \mathrm{L}^{-1}$ (normal $100-185$ ), serum glutamic oxaloacetic transaminase (SGOT) $74 \mathrm{IU} \cdot \mathrm{L}^{-1}$ (normal 7-40) and alkaline phosphatase $172 \mathrm{IU} \cdot \mathrm{L}^{-1}$ (normal 20-110). Hepatitis B surface antigen and core antibody were positive. The chest $x$-ray showed a prominent pulmonary artery and the heart size and pulmonary vasculature were at the upper limits of normal. The ECG was within normal limits. An echocardiogram showed hypertrophy of both atria and of the left ventricle. A cerebral angiogram showed an aneurysm at the right carotid bifurcation. Although the aneurysm was not producing symptoms, the patient was a candidate for liver transplantation and it was considered most appropriate to repair the aneurysm as the initial procedure.

The morning of surgery, two units of fresh frozen plasma were administered following which the PT was $14.2 \mathrm{sec}$. In the operating room, a $7 F$ balloon-tipped thermodilution Swan-Ganz catheter was placed via the right external jugular vein and a radial arterial catheter was placed, both under local anaesthesia. Haemodynamic values and blood gases pre-, intra-, and postoperatively are shown in Table 1. Anaesthesia was induced with sufentanil $100 \mu \mathrm{g}$ and droperidol $2.5 \mathrm{mg}$. Lidocaine $100 \mathrm{mg}$ IV and pancuronium $10 \mathrm{mg}$ were administered prior to 
TABLE I Hacmodynamics

\begin{tabular}{|c|c|c|c|c|c|}
\hline & Prior to induction & Post-induction & Hypotension & Post-hypotension & Post-op (ICU) \\
\hline $\mathrm{BP}(\mathbf{m m H g})$ & $120 / 76$ & $120 / 70$ & $70 / 40$ & $122 / 72$ & $130 / 70$ \\
\hline MAP (mmHg) & 90 & 86 & 50 & 88 & 88 \\
\hline PAP (mmHg) & $42 / 27$ & $45 / 31$ & $39 / 23$ & $38 / 26$ & $43 / 16$ \\
\hline PCWP $(\mathrm{mmHg})$ & 25 & 18 & 14 & 14 & 10 \\
\hline $\operatorname{CO}\left(L \cdot \min ^{-1}\right)$ & 12.5 & 11.0 & 9.1 & 8.1 & 12.5 \\
\hline SVR (dyne $\cdot \mathrm{s} \cdot \mathrm{cm}^{-5}$ ) & 460 & 524 & 330 & 750 & 525 \\
\hline \multicolumn{6}{|l|}{ Arterial blood gases } \\
\hline $\mathrm{pH}$ & 7.41 & 7.47 & 7.46 & 7.45 & 7.39 \\
\hline $\mathrm{PaCO}_{2}(\mathrm{mmHg})$ & 41 & 35 & 35 & 36 & 42 \\
\hline $\mathrm{PaO}_{2}(\mathrm{mmHg})$ & 61 & 268 & 199 & 319 & 85 \\
\hline $\mathrm{FIO}_{2}$ & 0.21 & 1.0 & 1.0 & 1.0 & 0.35 \\
\hline $\mathrm{PFO}_{2}(\mathrm{mmHg})$ & 46 & 59 & 52 & 54 & \\
\hline $\mathrm{SvO}_{2}(\%)$ & 80 & 88 & 84 & 87 & \\
\hline
\end{tabular}

$\mathrm{BP}=$ blood pressure, $\mathrm{MAP}=$ mean arterial pressure; $\mathrm{PAP}=$ pulmonary artery pressure; $\mathbf{P C W P}=$ pulmonary capillary wedge pressure; $\mathrm{CO}=$ cardiac output; $\mathrm{SVR}=$ systemic vascular resistance; $\mathrm{FIO}_{2}=$ fractional inspired $\mathrm{O}_{2} ; \mathrm{PVO}_{2}=$ mixed venous $\mathrm{PO}_{2}$; $\mathrm{Svv}_{2}=\%$ mixed venous $\mathrm{O}_{2}$ saturation.

tracheal intubation. Anaesthesia was maintained with sufentanil (total dose $200 \mu \mathrm{g}$ ), isofurane 0.20 per cent end-tidal, and oxygen 100 per cent. Additional monitoring included an ECG, mass spectrometer (providing endtidal and inspired analysis of $\mathrm{O}_{2}, \mathrm{~N}_{2} \mathrm{O}, \mathrm{CO}_{2}$, and isoflurane), ECG and a neuromuscular transmission monitor. Sodium nitroprusside, $3-5 \mu \mathrm{g} \cdot \mathrm{kg}^{-1} \cdot \mathrm{min}^{-1}$ and labetalol $30 \mathrm{mg}$ were used to lower mean arterial pressure (MAP $=2 / 3$ diastolic BP $+1 / 3$ systolic $\mathrm{BP}$ ) to $50 \mathrm{mmHg}_{\mathrm{g}}$ for 45 minutes during dissection and clipping of the aneurysm. Blood loss was estimated to be $800 \mathrm{ml}$. Four units of fresh frozen plasma and two units of packed red blood cells were administered intraoperatively. Neuromuscular relaxation was reversed with neostigmine $3.0 \mathrm{mg}$ and glycopyrrolate $0.6 \mathrm{mg}$. The patient awakened immediately postoperatively and was fully alert and responsive. In the postoperative period, no new neurological deficits developed and there was no significant change in transaminase values (Table II) and no clinically evident alterations in hepatic function. The patient was discharged home on the tenth postoperative day. Two months later a successful liver transplant was performed.

\section{Discussion}

Conflicting data exist on liver blood flow and metabolism during induced hypotension. In dogs, Gelman and Emst, ${ }^{3}$ using sodium nitroprusside (SNP), 10-20 $\mu \mathrm{g}^{\mathrm{kg}} \mathrm{kg}^{-1} \cdot \mathrm{min}^{-1}$, decreased MAP to $70 \mathrm{mmHg}$ (a 40 per cent change). While hepatic and portal blood fows sustained decreases, there were no changes in liver oxygen consumption or the liver lactate:pyruvate ratio. At higher concentrations of SNP (above $25 \mu \mathrm{g} \cdot \mathrm{kg}^{-1} \cdot \mathrm{min}^{-1}$ ), blood pressure declined more than 50 per cent, portal and hepatic flows decreasd 80 and 40 per cent respectively, and portal and hepatic venous oxygen contents declined $5 \mathrm{mlO}_{2} \cdot \mathrm{dl}^{-1}$ blood. Unfortunately, the authors eliminated this latter data set and did not analyze it in their report.

In contrast, Lagerkranser et al. ${ }^{4}$ decreased MAP in dogs to $50 \mathrm{mmHg}$, a 60 per cent change, using SNP at an average dose of $14 \mu \mathrm{g} \cdot \mathrm{kg}^{-1} \cdot \mathrm{min}^{-1}$. Portal venous flow initially decreased 16 per cent, then by 60 minutes returned to control, while hepatic arterial flow decreased 39 per cent over the study period. Oxygen uptake in the preportal tissues and the liver was unchanged, while hepatic oxygen extraction increased from both the hepatic arterial and portal venous systems. No significant alteration in hepatic lactate extraction was found. The authors concluded that SNP-induced hypotension to MAP $50 \mathrm{mmHg}$ resulted in a reduction in hepatic bload flow, but this change was balanced by increased hepatic oxygen extraction resulting in overall unchanged hepatic metabolism.

Dong et al. ${ }^{5}$ produced extreme hypotension (MAP $12-25 \mathrm{mmHg}$ ) in 20 dogs. Eight died, but among the

TABLE I] Enzymes and bilinbin

\begin{tabular}{|c|c|c|c|c|}
\hline$D a y$ & $L D H$ & SGOT & $A L K P$ & Bilirubin \\
\hline Day prior to surgery & 310 & 74 & 172 & 5.6 \\
\hline \multicolumn{5}{|l|}{ Post-op } \\
\hline Day 1 & 256 & 64 & 119 & 6.0 \\
\hline Day 2 & 273 & 61 & 113 & 6.8 \\
\hline Day 3 & 349 & 56 & 113 & 8.2 \\
\hline Day 5 & 273 & 56 & 95 & 6.4 \\
\hline Day 8 & 257 & 47 & 138 & 7.9 \\
\hline
\end{tabular}

$\mathrm{LDH}=$ lactate dehydrogejuse, $\mathrm{IU} \cdot \mathrm{L}^{-1}$, numal $100-185$; SGOT $=$ serum glutamic oxaloacetic acid transaminase, $1 \mathrm{U} \cdot \mathrm{L}^{-1}$, normal $7-40$; ALKP $=$ alkaline phosphatase, $\mathrm{JU} \cdot \mathrm{L}^{-1}$, normal 20-110; Bilirubin, $\mathrm{mg} \cdot \mathrm{dl}^{-1}$, normal $=0.5-1.0$. 
survivors, nearly all showed elevations in SGOT, serum glutamic pyruvic transaminase (SGPT), and alkaline phosphatase, as well as histological evidence of hepatic necrosis. CNS function, by neurological, behavioural and histological examinations, remained intact. These authors concluded that the liver was more susceptible to ischaemic damage from profound hypotension than the brain. None of these studies spccifically addressed the significance of duration of hypotension.

In a large group of patients undergoing total hip arthroplasty, MAP of $50 \mathrm{mmHg}$ was produced with halothane or SNP. ${ }^{6}$ No difference between postoperative SGPT, SGOT, serum bilirubin or alkaline phosphatase were detected in hypotensive versus non-hypotensive controls. In patients undergoing gynaecological surgery, ${ }^{\top}$ liver blood flow was assessed by clearance of indocyanine green (ICG) under normotensive and hypotensive conditions. At a MAP or $52-57 \mathrm{mmHg}$ produced either by SNP or lumbar epidural blockade, no changes in ICG clearance were noted. Two recent abstracts ${ }^{8,9}$ also reported no changes in ICG clearance at MAP ranging from $35-55 \mathrm{mmHg}$ produced by SNP or isoflurane. The data from these human studies show no apparent adverse effects of induced hypotension upon the liver in normal patients.

In our patient, labetalol, a combined alpha and betaadrenergic antagonist, was used as an adjuvant for induced hypotension. No information is available on its effects on hepatic blood flow and therefore its use may be questioned. Propranolol $0.1 \mathrm{mg} \cdot \mathrm{kg}^{-1}$ antagonizes the hepatic arterial or vasodilator response to isoproterenol but does not alter hepatic arterial or portal venous resistances. ${ }^{10}$ When given intraportally ( $1 \mathrm{mg} \cdot \mathrm{kg}^{-1}$ ), in the rat, it constricts hepatic sinusoids. ${ }^{10}$ The effects of alpha-adrenergic antagonists are more difficult to assess, but in rats, phenoxybenzamine, $1 \mathrm{mg} \cdot \mathrm{kg}^{-1}$ intraportally, dilates the liver sinusoids. ${ }^{10}$ The combined effects on the liver of alpha and beta blockade are not known.

It remains to be determined if the information known concerning liver blood flow and metabolism under hypotensive conditions in normal livers can be applied to patients such as ours. However, intraoperatively no evidence of impaired organ perfusion occurred, and postoperatively there was no clinical or laboratory evidence of any alteration in hepatic function.

While many agents are available for inducing hypo tension, SNP was chosen because of the previously cited evidence, albeit limited, that it produces minimal changes in hepatic blood flow and metabolism. Labetalol was chosen as an adjunct both to decrease heart rate and to maintain MAP at a stable value of $50 \mathrm{mmHg}$. It is entirely possible that other agents, alone or in combination, could have been used successfully as weli. Comparative stud- ies in humans or arimals would be necessary to clarify this issue.

In summary, we have shown the apparent safety of induced hypotension to MAP $50 \mathrm{mmHg}$ for 45 minutes using SNP and labetalol, in a patient with cirrhosis. It must be emphasized, however, that one does not know how representative this patient was of other patients with hepatic injury. Factors such as the presence of acute inflammation or the metabolic rate of the injured liver may modify the response to hypotension. Further studies of liver blood flow and metabolism in diseased livers during induced hypotension are needed in an animal model or in humans in order to define the safe limits of hypotension in this patient population.

\section{Acknowledgement}

The authors are grateful to Drs. Azmy Boutros and Michael Roizen for reviewing the manuscript.

\section{References}

1 Miller ED. Deliberate hypotension. Chap 55. In: Miller RD (Ed.) Anesthesia. 2nd ed. New York: ChurchillLivingstone, 1986; 1949-70.

2 Richardson $P D$, Withrington $P G$. Physiological regulation of the hepatic circulation. Ann Rev Physiol 1982; 44: 57-69.

3 Gelman S, Ermst EA. Hepatic circulation during sodium nitroprusside infusion in the dog. Anesthesiology 1978; 49: 182-7.

4 Lagerkranser $M$, Andreen $M$, Irestedt $L$. Central and splanchnic hacmodynamics in the dog during controlled hypotension with sodium nitroprusside. Acta Anaesthesiol Scand 1984; $28: 81-6$.

5 Dong WK, Bledsoe SW, Eng DY et al. Profound arterial hypotension in dogs: brain electrical activity and organ integrity. Anesthesiology 1983; 58: 61-71.

6 Thompson GE, Miller RD. Stevens WC, Murray WR. Hypotensive anesthesia for total hip arthroplasty: a study of blood loss and organ function (brain, heart, liver, kidney). Ancsthesiology 1978; 48: 91-6.

7 Abdel Salam AR, Drummond GB, Bauld HW, Scot DB. Clearance of indocyanine green as an index of liver function during cyclopropane anaesthesia and induced hypotension. Br J Anaesth 1976; 48: 231-7.

8 Chauvin MD, Bonnet $F$, Montembault $C$, Lafay $M$, Viars $P$. Hepatic ptasma flow during sodium nitroprusside. induced hypotension in man (Abstract). Anesthesiology 1984; 61: A265

9 Lam AM, Herd SF, Mustard RF, Manninen PH, Gelb AW. Hepatic blood flow during isolurane-induccd hypotension in man (Abstract). Anesthe siology 1985; 63: A404. 
10 Richardson $P D$, Withrington $P G$. Liver blood flow II:

Effects of drugs and hormones on liver blood flow. Gastroenterology $1981 ; 81: 356-75$.

\section{Résumé}

L'hypotension contrôlée fut utilisée chez un patient atteint de cirrhose el d'une hépatite chronique active se présentant pour clampage d'un anévrysme intracrânien. Une pression artérielle moyenne de $50 \mathrm{mmHg}$ était induite avec du nitroprussiate er du labétolol. Le patient n'a démoniré aucun changement postopératoire dans sa fonction hépatique. Des études antérieures ont examiné les effets de l'hypotension contrólée sur la fonction hépatique normale. Relativement peu d'information est disponible sur les effets de l'hypotension contrôlée en présence d'une atteinte hépatique. L'absence d'effets secondaires chez ce patient n'est cependant pas une preuve de la sécurité de cette rechnique chez les patients atteints de maladie hépatique. D'aurres études sur ce groupe de parients sont requises. 